Journal of Aquaculture Feed Science and Nutrition 2 (1): 1-5, 2010

ISSN: $2070-1667$

(C) Medwell Journals, 2010

\title{
Production of Anti WSSV IgY Edible Antibody Using Herbal Immunoadjuvant Asparagus racemosus and its Immunological Influence against WSSV Infection in Penaeus monodon
}

\author{
Thangamani Kumaran, Mariavincent Michaelbabu, Thangasamy Selvaraj, \\ Sathiyadhas Albindhas and Thavasimuthu Citarasu \\ Centre for Marine Science and Technology, Manonmaniam Sundaranar University, \\ Rajakkamangalam, Kanyakumari, 629502 Tamil Nadu, India
}

\begin{abstract}
Country Fowl, Gallus domesticus were immunized with inactivated WSSV and produced anti WSSV $\operatorname{Ig} Y$ by with and without hot water extracts of the immunoadjuvant, Asparagus recemosus. Simultaneously, Ig Y was prepared without the injection of inactivated WSSV. IgY and anti WSSV IgY were coated with artificial diets and fed to the shrimp P. monodon juvenile for 30 days and after that they were challenged with WSSV. The anti WSSV IgY coated diets fed shrimps were highly resist against the WSSV challenge and improve the to the growth characteristics significantly $(\mathrm{p}<0.01$ ). The antibody produced by immunoadjuvant boosted anti WSSV IgY fed $P$. monodon exhibited had increased total haemocyte count $\left(45 \times 10^{3}\right.$ cell $\left.\mathrm{mL}^{-1}\right)$, oxyhaemocyanin $\left(1.38 \mathrm{mmol}^{-1}\right)$ and decreased time $(89 \mathrm{sec})$ of coagulase activity. Also the immunological parameters such as phenol oxidase, lysozyme activity and intracellular superoxide anion production were significantly $(\mathrm{p}<0.01)$ increased from the control group.
\end{abstract}

Key words: Penaeus monodon, edible yolk antibody Ig Y, immuno adjuvant, WSSV, producation, India

\section{INTRODUCTION}

White Spot Syndrome Virus (WSSV) is an economically significant shrimp disease which causes high mortalities and severe damages to shrimp cultures (Hameed et al., 1998). The treatment protocol of currently applied methods are rather difficult, non-effective, costly and involves environmental hazards (Verpraet et al., 1992). In shrimp aquaculture, farmers are understood the bad effect of antibiotics and they are now shifting over to safety biotechnological eco friendly approaches such as immunostimulants (Citarasu et al., 2006) vaccines and edible antibodies (Liang et al., 2006), etc. Egg yolk antobodies could be uesed for either developing the immunodiagnostics or in the passive immunotherapy as a prophylactic measure in the management of fish and shellfish diseases.

The yolk of eggs laid by immunized chickens has been recognized as an excellent source of polyclonal Antibodies (pAb) for over a decade. Specific antibodies produced in choickens offer several important advantages over producing antibodies in other mamals. Because a single egg contains as much antibody as an average bleed from rabbit, this simple, non-invasive approach presents an appealing alternative to conventional pAb production methods (Paniprasad, 2009). The present study mainly focus on the production of anti WSSV yolk edible antibody, IgY using inactivated WSSV and herbal immuno adjuvant extract, $A$. racemosus through the hen Gallus domesticus. In order to get more and highly immunoreactive antibody, immuno adjuvant is essential. It is well known that chemical adjuvant have many disadvantages such as side effects, strong local stimulation and carcinogenesis together with complicated preparations or failure to increase immunogencity of weak antigen and so on (Bowersock and Martin, 1999). Recently, herbal immuno adjuvant is highly influenced to enhance the antibody production in animal models (Patwardhan, 2000). Moreover, the alternative herbal substances possessing the interesting properties like non-toxic, biodegradable and biocompatible (Citarasu et al., 2003). Medicinal plants including Withania somnifera, Tinospora cordifolia and Asparagus racemosus, demonstrated significant immuno stimulatory activity particularly at humoral level in experimental systems with (or) with out included immunosuppression (Ziauddin et al., 1996). The efficiency anti WSSV IgY produced by herbal immuno adjuvant were discussed in this study against WSSV infection on Penaeus monodon by haematological, biochemical and immunological approach.

\section{MATERIALS AND METHODS}

Source of WSSV: Purified WSSV were kindly provided by Dr. V. Murugan, Asst. professor, Centre for

Corresponding Author: Thavasimuthu Citarasu, Centre for Marine Science and Technology, Manonmaniam Sundaranar University, Rajakkamangalam, Kanyakumari, 629502 Tamil Nadu, India 


\section{J. Aquacult. Feed Sci. Nutr., 2 (1): 1-5, 2010}

Biotechnology, Anna University, Tamil Nadu Chennai, India. WSSV isolated from infected shrimps which was collected from infected farms of Nellore, Andra Pradesh, India and semi purified by ultracentrifugation following the method of Hameed et al. (1998):

Immuno adjuvant and inactivated vaccines: $A$. racemosus tubers were extracted with hot water at $100^{\circ} \mathrm{C}$ at least $2 \mathrm{~h}$. The extracts were filtered and the supernatant were condensed by rotary evaporator at $55^{\circ} \mathrm{C}$, lyophilized and stored $4^{\circ} \mathrm{C}$. The semi purified WSSV suspensions were diluted with 10 fold of $1 \mathrm{X}$ PBS and inactivated by $0.5 \%$ $\mathrm{V} / \mathrm{V}$ formalin for $10 \mathrm{~min}$ at $25^{\circ} \mathrm{C}$. Formalin was removed by two time centrifugations at $30,000 \times \mathrm{g}$ for $1 \mathrm{~h}$ at $4^{\circ} \mathrm{C}$. The pellet was resuspended in PBS to furnish the viral concentration of one tenth of the original viral stock solution and used as a vaccine. About $500 \mathrm{mg}$ of $A$. recemosus hot water extract were mixed with inactivated WSSV suspension having $700 \mu \mathrm{g}$ of total protein and make up to $1 \mathrm{~mL}$ of PBS.

Immunization: Three groups of lay off period country fowl, $G$. domesticus were reared in separate cages. Each groups had two hens and the 1st group was injected in the breast with $1 \mathrm{~mL}$ of heat inactivated WSSV having $700 \mu \mathrm{g}$ of total protein. The second group was injected with $1 \mathrm{~mL}$ inactivated WSSV with immuno adjuvant, $A$. recemosus hot water extract. The third group was injected with the $1 \mathrm{X}$ PBS as a control experiment. Injections were repeated to breast of the hen every 7 days for the same respective doses of each groups up to 1 month. Eggs began to be collected 5 weeks after the 1st inoculation. The eggs were collected separately marked and stored at $4^{\circ} \mathrm{C}$ until antibody isolation.

IgY and anti WSSV IgY production and purification and immunodiffusion: Egg yolk were carefully removed from the albumin, washed with distilled water to remove the albumin, open and mixed with $1: 3$ pre-cooled $\left(-20^{\circ} \mathrm{C}\right)$ isopropyl alcohol at $5^{\circ} \mathrm{C}$ for $5 \mathrm{~min}$. This produce was repeated three times with isopropyl alcohol wash and twice with pre chilled $\left(-20^{\circ} \mathrm{C}\right)$ acetone for complete removal of lipids. The final residue was filtered with What man no. 1 filter study, washed with a small amount of acetone and left to dry room temperature. The resultant powder was a mixture of yolk proteins including antibodies and was stored at $5^{\circ} \mathrm{C}$ until used. Further, the antibodies were run by $12 \%$ SDS-PAGE. To examine the immuno reactivity between whole WSSV antigen and anti WSSV IgY, double immunodiffusion method were followed by Ouchterlony (1962). Anti WSSV Ig Y and Ig Y were six fold diluted against whole inactivated WSSV antigen.
Diet preparation with antibody coating: Ingredients and formulation of the basal ration were followed as described by Boonyaratpalin (1993). The basal diet contained 45\% protein, $7.2 \%$ Lipid, $14.6 \%$ ash, $7.1 \%$ moisture and $3 \%$ fibre. Freeze died pellet feeds were coated with $2 \%$ anti-WSSV IgY and IgY using cod liver oil. They are stored at $-20^{\circ} \mathrm{C}$ deep freezer for further feeding to the culture experiments.

Experimental set-up and feeding: Healthy $P$. monodon weighing approximately $10.0 \pm 1.0 \mathrm{~g}$ were stocked in individual fibre tanks (1000 1 capacity) namely blank control, control (IgY), anti WSSV IgY raised without immuno adjuvant (D1) and anti WSSV IgY raised with immuno adjuvant (D2) in triplicate $(n=30 \times 3=90)$. The experimental shrimps were fed with antibody coated feed with twice a day at 8.00 and $20.00 \mathrm{~h}$ at $10 \%$ of body weight. Also, uncoated normal feeds were fed to all experimental and control groups at 12.00 and $16.00 \mathrm{~h}$. Uneaten food and waste matters were removed before feeding.

WSSV challenge and cumulative mortality: Twenty shrimps of the control and experimental groups were challenged with virulent WSSV by injecting $25 \mu \mathrm{L}$ of semi purified WSSV having the protein concentration of $300 \mu \mathrm{g}$ after 30 th day of feeding. In blank control group, $25 \mu \mathrm{L}$ of PBS were injected instead of WSSV. After injection, the shrimps were subdivided randomly into two clusters (A and B). Twenty animals are introduced in cluster A separately in a fiber glass tank $(1000 \mathrm{~L})$ for studying the cumulative mortality up to 20 days. From the cluster B, 70 animals are introduced other tank for analyze the haematological and immunological parameters.

Haematological parameters: To find out the coagulase activity, haemolymph was withdrawn from the pericardial sinus using No. 24 hypodermic needle without anticoagulant. The clotting time was determined following the procedure described by Peters and Long (1973). Total haemocyte count (cells $\mathrm{mL}^{-1}$ ) was performed using a Burker haemocytometer. Oxyhaemocyanin was calculated following the method of Hagerman (1983).

Immunological parameters: Prophenol oxidase activity in haemolmph samples was determined using L-dihydroxyphenylalanine (L-DOPA) as a substrate following the method of Soderhall et al. (1986). Enzyme activity was expressed as units defined as the amount of enzyme giving an increase in absorbance at $490 \mathrm{~nm}$ of $0.001 \mathrm{~min}^{-1} \mathrm{mg} /$ protein. Superoxide anion was quantified which followed the method of Song et al. (1997). The optical density of the dissolved formazan was read at $630 \mathrm{~nm}$ and comparing the effects of different treatment on the generation of $\mathrm{O}_{2}$ in all tested groups. Intra-agar 
Lysozyme activity was performed against the Micrococcus luteus culture. The serious haemocytes dilution was delivered a single drop to the agar wells. Allowed the drops to absorb in to the agar and incubated them upside down for $24-48 \mathrm{~h}$ at $37^{\circ} \mathrm{C}$. Score the plates for the highest dilution of haemocytes capable of lysing the test microorganisms.

Data analysis: All data obtained from experiments were analysed using one way ANOVA ( $\mathrm{p}<0.05$ as significant level) in Statistica 6.0 computer package (Statsoft, UK). Means were also compared using SNK test.

\section{RESULTS AND DISCUSSION}

The SDS-PAGE profile revealed that there is a protein having the molecular weight of around $37 \mathrm{kDa}$ in the anti WSSV IgY immunoglobulin of the chick yolk G. domesticus produced by with and without immunoadjuvant $A$. racemosus. The immuno adjuvant A. racemosus helps to increase the yield of anti WSSV Ig Y immunoglobulin production (Fig. 1) compare to the lane 2 and there is no specific protein was expressed in the lane 1 . Chicken egg yolk antibody (IgY) has received much attention in recent years because it can be easily prepared in high concentration and is both affordable and safe (Gassmann et al., 1990). Novel adjuvants such as purified saponins, immunostimulatory complexes and liposomes, have been shown to greatly improve the induction of Major Histocompatibility Complex (MHC) class I-restricted CD81 Cytotoxic T Lymphocyte (CTL) responses. Recently, A. racemosus is used as a good adjuvant in human diseases (Patwardhan, 2000) and give an efficient and sustained immunostimulation to improve immunogenicity of weak or low dose of antigens. Also the immuno adjuvant $A$. racemosus helps to increase the immuno reactivity between the inactivated whole WSSV and anti WSSV Ig Y antibody (Table 1). The anti WSSV Ig Y produced by without immuno adjuvant react up to 1:16 dilutions and surprisingly the anti WSSV $\operatorname{Ig} Y$

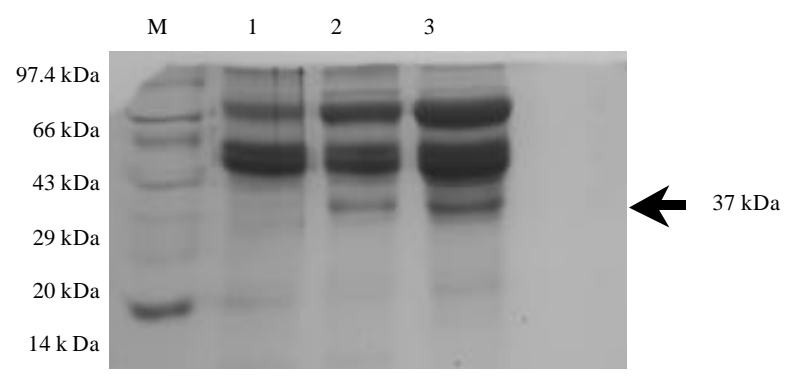

Fig. 1: Production of yolk antibody, Ig Y against WSSV using different methods. Lanes: M: Marker; 1: IgY; 2: Anti WSSV Ig Y produced by without adjuvant; 3: Anti WSSV IgY produced by immuno-adjuvant antibody produced with immuno adjuvant react 1:32 dilutions. Egg yolk immunoglobulin (IgY) from hens immunized with inactivated WSSV and DNA vaccine was obtained, purified and used for protection of Metapenaeus ensis against WSSV (Lu et al., 2008) and this was successfully neutralize WSSV and help to increased survival. Kim et al. (2004) showed that WSSV can be neutralized by chicken IgY produced against a truncated fusion protein of VP28 and VP19 and passive immunization with the IgY against WSSV has potential for immunotherapeutic application to prevent WSSV infection in shrimp. Cumulative mortality of the P. monodon PL challenged with WSSV after the experimental culture revealed that the immuno adjuvant is highly influenced in the in vivo system of shrimp (Fig. 2). The shrimps are succumbed to death $100 \%$ mortality with in 8 days when no antibody given. Surprisingly, the diet D2 helps to reduce the cumulative mortality of only $80 \%$ with in 20 days and the D1 had the reduction is $50 \%$ and significantly $(\mathrm{p}<0.05)$ differed. The anti WSSV IgY was more effective against WSSV infections in shrimps and might also function to prevent the virus adhesion to the host cells, an essential step for the establishment of viral infections. The anti WSSV antibody Another factor may be due to the intrinsic bacteriostatic nature of the immunoglobulin which interfere reduction in the viral load ( Liang et al., 2006). The highly improved haematological parameters also found in the experimental diets due to the

Table 1: Double immunodiffusion reactivity between WSSV antigen and IgY antibody produced against WSSV by different approaches

\begin{tabular}{lccc}
\hline & Reactivity between WSSV antigen and IgY antibody \\
& & IgY produced by & IgYproduced \\
& & without adjuvant & by adjuvant \\
Dilutions & Control & - & ++ \\
$1: 1$ & - & +++ & +++ \\
$1: 2$ & - & +++ & +++ \\
$1: 4$ & - & ++ & +++ \\
$1: 8$ & - & + & ++ \\
$1: 16$ & - & - & + \\
\hline
\end{tabular}

-: No reactivity; +: low reactivity; + : moderate reactivity; ++ : higher reactivity

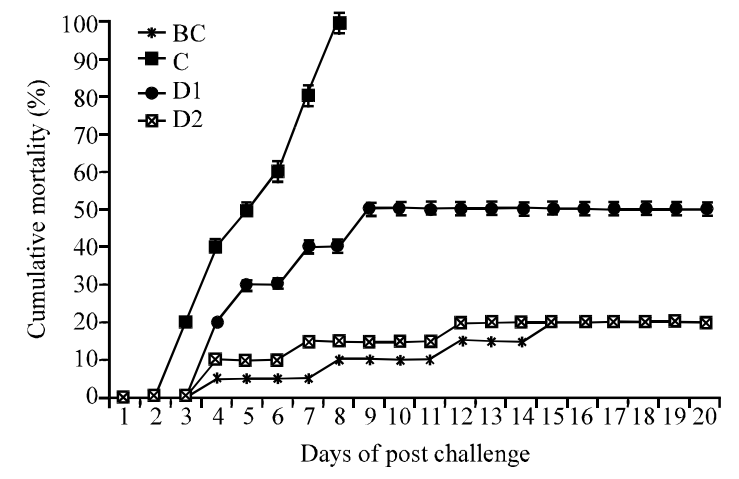

Fig. 2: Cumulative mortality of $P$. monodon challenged WSSV after post vaccination 
Table 2: Haematological parameters of $P$. monodon challenged WSSV after post vaccination

\begin{tabular}{|c|c|c|c|}
\hline Treatments & $\begin{array}{l}\text { Coagulase } \\
\text { time }(\mathrm{sec})\end{array}$ & $\begin{array}{c}\text { Total haemocyte } \\
\text { count }\left(\times 10^{3} \text { cell } \mathrm{mL}^{-1}\right)\end{array}$ & $\begin{array}{c}\text { Oxy haemocyanin } \\
\left(\mathrm{mmol}^{-1}\right)\end{array}$ \\
\hline Blank control & $150.33 \pm 3.39^{a}$ & $39.66 \pm 1.69^{\mathrm{a}}$ & $0.94 \pm 0.02^{\mathrm{a}}$ \\
\hline Control (IgY) & $171.66 \pm 3.85^{b}$ & $28.00 \pm 0.81^{b}$ & $0.70 \pm 0.03^{b}$ \\
\hline $\begin{array}{l}\text { Anti WSSV } \\
\text { IgY without } \\
\text { adjuvant (D1) }\end{array}$ & $125.33 \pm 3.09^{\circ}$ & $35.66 \pm 1.69^{c}$ & $0.91 \pm 0.01^{\mathrm{a}}$ \\
\hline $\begin{array}{l}\text { Anti WSSV } \\
\text { IgY with } \\
\text { adjuvant (D2) }\end{array}$ & $96.00 \pm 0.81^{\mathrm{d}}$ & $45.00 \pm 2.44^{\mathrm{d}}$ & $1.08 \pm 0.04^{c}$ \\
\hline
\end{tabular}

effect of anti WSSV IgY antibodies. There is the decreased times for the coagulase activity observed in the D2 diets $(96 \mathrm{sec}$ ) where as in control group of $171 \mathrm{sec}$ for coagulation due to the effect of antibodies. The Total Haemocyte Count (THC) of the control group of $28 \times 10^{3}$ cells $\mathrm{mL}^{-1}$. This was significantly $(\mathrm{p}<0.05)$ increased 35 and $45 \times 10^{3}$ cells $\mathrm{mL}^{-1}$ in $\mathrm{D}_{1}$ and $\mathrm{D}_{2}$ groups, respectively. The higher $\mathrm{THC}$ in the $\mathrm{D} 2$ is responsible for immunoadjuvant. The level of oxyhaemocyanin also significantly $(p<0.05)$ increased from the control group to experimental groups (Table 2). Like the hematological parameters, immunological parameters are also improved the same manner in the D1 and D2 groups. For Pro PO and intracellular superoxide anion production $\left(\mathrm{O}_{2}{ }^{-}\right)$, all shrimps were succumbed to death within 6 days in the control group due to no immunogenicity. Surprisingly, the D1 and D2 groups had significantly $(\mathrm{p}<0.05)$ increased the Pro PO and intracellular superoxide anion production $\left(\mathrm{O}_{2}^{-}\right)$value due to immune enhancement by the anti WSSV antibody IgY produced by with and without immuno adjuvant $A$. racemosus (Fig. 3 and 4).

The intra-agar lysozyme assay revealed that the activity was significantly increased $(p<0.05)$ to the experimental groups D1 and D2 from the control group. The control group had decreased Lysis activity due to no immune enhancement (Table 3). Haemocytes are responsible for clotting, exoskeleton hardening, elimination of foreign materials, molting and development of organs (Song et al., 1997). Maeda et al. (1997) have observed a decline in total hemocyte count in shrimp infected with penaeid rod-shaped DNA virus. The possibility is that the THC decline would be due to cell burst resulting from budding of the virus or by virus induced apoptosis, since this type of cell suicide may be induced or repressed during some viral infections (Cohen, 1993). The present study revealed that the anti WSSV IgY produced with $A$. racemosus helped to decrease the time of clotting of $50 \%$, increased haemocyte count of around $75 \%$ from control. Methanolic extracts of five different herbal medicinal plants like Cyanodon dactylon, Aegle marmelos, Tinospora cordifolia, Picrorhiza kurooa and Eclipta alba were highly influenced and significantly had more survival, reduction in the viral load and better performance of
Table 3: Zone formation ( $\mathrm{mm}$ ) of Intra-agar Lysozyme activity of the haemolymph of $P$. monodons fed with IgY and anti WSSV IgY coated diets and challenged WSSV after 30 days post vaccination Reactivity between WSSV antigen and IgY antibody

\begin{tabular}{llcc} 
& \multicolumn{2}{c}{ Reactivity between WSSV antigen and IgY antibody } \\
& - & $\begin{array}{c}\text { IgY produced by } \\
\text { without adjuvant (D1) }\end{array}$ & $\begin{array}{c}\text { IgY produced } \\
\text { by adjuvant (D2) }\end{array}$ \\
Dilutions & Control & $0.0 \pm 0.0$ & $0.00 \pm 0.0$ \\
Blank $\left(\mathrm{DH}_{2} \mathrm{O}\right)$ & $0.0 \pm 0.0$ & $10.6 \pm 0.4^{\mathrm{b}}$ & $14.00 \pm 0.8^{\mathrm{c}}$ \\
$10^{1}$ & $8.6 \pm 0.4^{\mathrm{a}}$ & $9.0 \pm 1.6^{\mathrm{b}}$ & $12.33 \pm 0.4^{\mathrm{c}}$ \\
$10^{2}$ & $6.0 \pm 0.8^{\mathrm{a}}$ & $5.3 \pm 0.4^{\mathrm{b}}$ & $7.60 \pm 1.2^{\mathrm{c}}$ \\
$10^{3}$ & $4.0 \pm 0.8^{\mathrm{a}}$ &
\end{tabular}

${ }^{\mathrm{a}-\mathrm{c}}$ Do not differ from each other $(\mathrm{p}<0.05)$

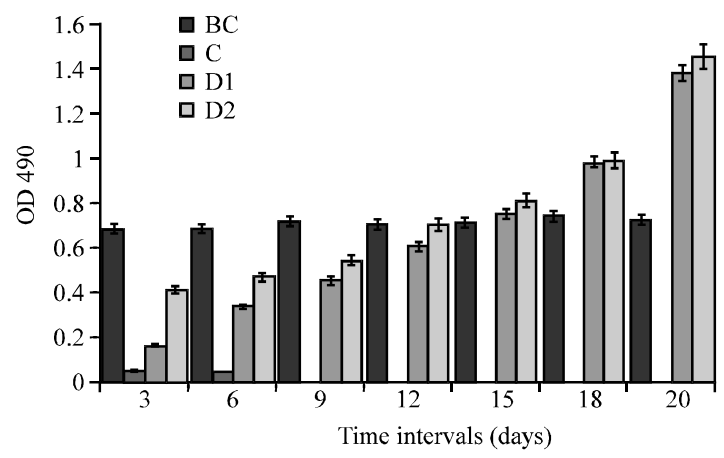

Fig. 3: Pro phenol oxidase of $P$. monodon challenged WSSV after post vaccination

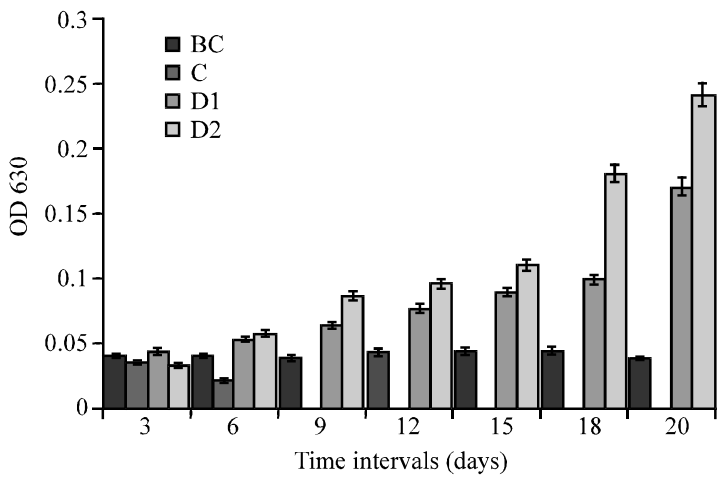

Fig. 4: Intracellular superoxide anion production (NBT assay) of $P$. monodon challenged WSSV after post vaccination

haematological, biochemical and immunological parameters (Citarasu et al., 2006). Prophenol oxidase, the key enzyme in the synthesis of melanin, occurs in haemolymph as an inactive pro-enzyme prophenoloxidase (proPO) and stimulate several cellular defence reactions, including phagocytosis, nodule formation, encapsulation and haemocyte locomotion (Soderhall et al., 1986). The activated haemocytes also produce extra bactericidal substances such as $\mathrm{H}_{2} \mathrm{O}_{2}$ and superoxide anion $\left(\mathrm{O}_{2}{ }^{-}\right)$that may increase disease resistance (Song et al., 1997). In the study, $A$. racemosus had highly influenced to enhance the immunological parameters such as $\mathrm{PO}$, intracellular superoxide anion production and lysozyme activity against the WSSV infection. The present study concluded 
that the active compounds such as saponin of the $A$. racemosus induce the immune system and produce higher amount of anti WSSV IgY pAb. The antibody may bind and neutralize the WSSV by the time the shrimp had more survival and growth rate, etc. Also, the pAb antibody boost the haemocytes as well as the immune system and the neutralization capacity of the host immune system will be improved. The present study clearly indicates that the edible yolk antibody Ig Y raised with immuno adjuvant $A$. racemosus and its effects are highly applicable to against the WSSV infection in the aquaculture industry.

\section{ACKNOWLEDGEMENTS}

One of the researchers Dr. T. Citarasu gratefully acknowledges the University Grant Commission (UGC) India for its financial support in the form of a research grant(UGCMajor Project-No. 37-271 (SR) dtd01.02.2010).

\section{REFERENCES}

Boonyaratpalin, M., 1993. Nutritional requirements of grouper Epinephelus. Proceeding of Grouper Culture, (GC'93), Thailand, National Institute of Costal Aquaculture, pp: 50-55.

Bowersock, T.L. and S. Martin, 1999. Vaccine delivery to animals. Adv. Drug Deliv. Rev., 38: 167-194.

Citarasu, T., R. Rajajeyasekar, K. Venketramalingam, P.S. Dhandapani and M.P. Marian, 2003. Effect of wood apple Aegle marmelos, Correa (Dicotyledons, Sapindales, Rutaceae) extract as an antibacterial agent on pathogens infecting prawn (Penaeus indicus) lariviculture. Indian J. Mar. Sci., 32: 156-161.

Citarasu, T., V. Sivaram, G. Immanuel, N. Rout and V. Murugan, 2006. Influence of selected Indian immunostimulant herbs against White Spot Syndrome Virus (WSSV) infection in black tiger shrimp, Penaeus monodon with reference to haematological, biochemical and immunological changes. Fish Shellfish Immunol., 21: 372-384.

Cohen, J.J., 1993. Overview: Mechanisms of apoptosis. Immunol. Today, 14: 123-130.

Gassmann, M., P. Thommes, T. Weiser and U. Hubscher, 1990. Efficient production of chicken egg yolk antibodies against a conserved mammalian protein. FASEB J., 4: 2528-2532.

Hagerman, L., 1983. Haemocyanin concentration of juvenile lobster (Homarus gammarus) in relation to molting cycle and feeding conditions. Mar. Biol., 77: 11-17.

Hameed, A.S.S., M. Anilkumar, M.L.S. Raj and K. Jayaraman, 1998. Studies on the pathogenicity of systemic ectodermal and mesodermal baculovirus and its detection in shrimp by immunological methods. Aquaculture, 160: 31-45.
Kim, D.K., I.K. Jang, H.C. Seo, S.O. Shin, S.Y Yang and J.W. Kim, 2004. Shrimp protected from WSSV disease by treatment with egg yolk antibodies (IgY) against a truncated fusion protein derived from WSSV. Aquaculture, 237: 21-30.

Liang, L., L.S. Bing and T.W. Huan, 2006. Protection of Carassius auratus Gibeligo against infection by Aeromonas hydrophila using specific immunoglobulins from hen egg yolk. J. Zhejiang Univ. Sci., 7: 922-928.

Lu, Y, J. Liu, L. Jin, X. Li and Y. Zhen et al., 2008. Passive protection of shrimp against white spot syndrome virus (WSSV) using specific antibody from egg yolk of chickens immunized with inactivated virus or a WSSV-DNA vaccine. Fish Shellfish Immunol., 25: 604-610.

Maeda, M., T. Itami, M. Kondo, O. Henning, Y. Takahashi, I. Hirono and T. Aoki, 1997. Characterisitcs of penaeied rod shaped DNA virus of kuruma shrimp. Proceedings of NRIA International Workshop: New Approaches to Viral Disease of Aquatic Animals, Jan. 21-24 National Research Institute of Aquaculture, Nansei, pp: 218-228.

Ouchterlony, O., 1962. Diffusion-in-gel methods for immunological analysis. II. Prog. Allergy, 6: 30-154.

Paniprasad, K., 2009. Edible antibodies in fish health management. Training Manuel of ICAR Sponsored Winter School on Genome and Protein Based Techniques in Aquatic Animal Health Management, 2-22 February, 2009, CIFE, Mumbai, India.

Patwardhan, B., 2000. Ayurveda: The Designer medicine: A review of ethnopharmacology and bioprospecting research. Indian Drugs, 37: 213-227.

Peters, R.I. and G.E. Long, 1973. Some alternation in haemolymph protein of Hemiorapaus nudus associated with temperature acculimation. Comp. Biochem. Physiol., 46: 207-213.

Soderhall, K., V.J. Smith and M.W. Johansson, 1986. Exocytosis and uptake of bacteria by isolated haemocyte populations of two crustaceans: Evidence for cellular co-operation in the defense reactions of arthropods. Cell Tissue Res., 2: 43-49.

Song, Y.L., J.J. Liu, L.C. Chan and H.H. Sung, 1997. Glucan-induced disease resistance in tiger shrimp (Penaeus monodon). Dev. Biol. Stand., 90: 413-421.

Verpraet, R., M. Chair, P. Leger, H. Nelis, P. Sorgeloos and A. De-Leenheer, 1992. Live-food mediated drug delivery as a tool for disease treatment in larviculture. The enrichment of therapeutics in rotifers and Artemia nauplii. Aquacult. Eng., 11: 133-139.

Ziauddin, M., N. Phansalkar, P.S. Patki, S. Diwanay and B. Patwardhan, 1996. Studies on immunomodulatory effects of Ashwagandha. J. Ethnopharmacol., 50: 69-76. 